\section{Early Blight Forecasting Systems: Evaluation, Modification, and Validation for Use in Fresh-market Tomato Production in Northern New Jersey}

\author{
W.P. Cowgill, Jr., ${ }^{1}$ M.H. Maletta, ${ }^{2}$ T. Manning, ${ }^{3}$ W.H. Tietjen, ${ }^{4}$ \\ S.A. Johnston, ${ }^{5}$ and P.J. Nitzsche ${ }^{6}$ \\ Rutgers Cooperative Extension of Hunterdon County, P.O. Box 2900, \\ Flemington, NJ 08822-9058
}

Additional index words. Lycopersicon esculentum, Alternaria solani, anthracnose, Colletotrichum coccodes, Septoria lycopersici, septoria leaf spot, powdery mildew, Oidiopsis sicula, chlorothalonil, copper hydroxide, mancozeb, azoxystrobin

\begin{abstract}
Research trials, conducted from 1991 to 1998, evaluated early blight forecasting systems for use in fresh-market tomato (Lycopersicon esculentum) production in northern New Jersey. Initial trials focused on determining which of three forecast systems-NJFAST, CU-FAST, TOM-CAST — would optimize fungicide use. The TOM-CAST system generated fungicide application schedules that reduced foliar disease rating compared to the untreated check and, in 1 year, controlled diseases as well as a weekly schedule with 3 rather than 14 applications. TOM-CAST was easier to use than NJ-FAST or CUFAST because it required fewer weather data inputs and simpler forecast calculations. Subsequent trials evaluated and defined thresholds for using TOM-CAST in northern New Jersey and evaluated the efficacy of several fungicides with TOM-CAST. Of the six TOM-CAST modifications evaluated, TOM-CAST beginning fungicide applications at 25 cumulative dew severity values (dew SV) and reapplying fungicide at 15 or 25 cumulative dew SV reduced disease rating as much as a weekly schedule in 1995 and 1996 and with fewer applications. After 5 years of trials, decision thresholds for using TOM-CAST in northern New Jersey were chosen and this new version of the forecast system designated NJ-TOM-CAST. It was verified in 1997 and 1998 and shown to generate fungicide application schedules that reduced foliar disease rating compared to the untreated check in both years and as much as the weekly schedule in one year. From 1995 through 1998, the conservative TOM-CAST schedules, TOM-CAST 25-15 or NJ-TOM-CAST, required on average 6 fungicide applications per year compared to weekly schedules that required on average 15 applications per year. In 1996, marketable yield was increased with TOMCAST scheduled treatment compared to the untreated check and was the same as or greater than yield with weekly treatment. In the other 3 years, fungicide applications, whether applied on a calendar-based or TOM-CAST-based schedule, did not increase marketable yields compared to the untreated check. Fungicides shown to be effective when used with NJ-TOM-CAST schedules included both low cost and new chemistry materials. Copper fungicides, some of which are allowed in organic crop production, did not consistently control fungal diseases when applied on the NJ-TOM-CAST schedule. Applying fungicides on the NJ-TOM-CAST schedule instead of calendar-based schedules did not increase bacterial disease severity. Powdery mildew damage was more severe with NJ-TOM-CAST-scheduled applications than weekly applications in 1 year, affirming the importance of disease monitoring in the field when using NJ-TOM-CAST. By 2000, through a cooperative effort of Rutgers Cooperative Extension and SkyBit, Inc. (Boalsburg, Pa.), a commercial weather service, NJ-TOM-CAST was available to northern New Jersey tomato growers by subscription.
\end{abstract}

Early blight, caused by Alternaria solani, is a serious foliar fungal disease of tomatoes where warm and humid conditions prevail. It can cause severe defoliation resulting in decreased marketable yields. Intensive calendar-based fungicide application programs have typically been followed to control this disease. During the 1970's and 1980's, three tomato early blight forecast systems were developed and validated: FAST (Forecaster of Alternaria solani on Tomato) (Madden et al., 1978; Pennypacker et al., 1983) in Pennsylvania; CU-FAST (Cornell University Forecaster of Alternaria solani on Tomato) (Sandlan and Zitter, 1989, rev. 1992) in New York; and TOM-CAST (Tomato Disease Forecaster) (Pitblado, 1988) in Ontario Canada. FAST was subsequently modified and designated PA-FAST (MacNab and Pennypacker, 1982). The premise for use of disease forecasting in crop production is that disease control materials can be applied as needed, when disease development is likely, rather than on a calendar-based schedule. Benefits accruing from forecast system scheduling might include lower cost of disease control and decreased pesticide input to the environment. Gleason and others (1995) reviewed the progress of and outlook for tomato disease forecasting and pointed out that "The progress [in development and use of tomato disease forecast systems] represents one of the greatest successes yet achieved in implementing a disease-warning system in North American agriculture," but concluded that "Diseasewarning systems must continue to improve in reliability, affordability, convenience...to remain relevant in the future".

PA-FAST, CU-FAST and TOM-CAST all use the FAST dew model, which relates daily hours of leaf wetness and temperature during wetness to disease risk, to determine daily disease severity values and generate forecasts. Daily disease severity values, designated as "S" or "DSV" by others (Madden et al., 1978; Pitblado, 1988; Sandlan and Zitter, 1989, rev. 1992), are designated "dew SV" for this report. But there are differences among them. TOMCAST forecasts are based on the FAST dew model alone while PA-FAST and CU-FAST also incorporate a rain model that determines five day disease severity rating values that are included in the forecast decision. The rain model relates the 5-d mean air temperature and number of hours relative humidity exceeds $90 \%$ and $7-d$ total rainfall to daily disease risk. Five-day disease severity rating values, designated "R" by others (Madden et al., 1978; Sandlan andZitter, 1989, rev. 1992), are designated "rain SV" for this report. CU-FAST estimates leaf wetness through calculations based on relative humidity and rainfall, while PAFAST and TOM-CAST use estimates based on monitoring with leaf wetness sensors. TOM-CAST was validated for controlling early blight, septoria leaf spot (Septoria lycopersici) and anthracnose 
Table 1. Nitrogen applications for early blight forecasting trials, 1991-98.

\begin{tabular}{lcc}
\hline & \multicolumn{2}{c}{ Nitrogen } \\
\cline { 2 - 3 } & $\begin{array}{c}\text { Preplant } \\
\text { incorporated } \\
\left(\mathrm{kg} \cdot \mathrm{ha}^{-1}\right)\end{array}$ & $\begin{array}{c}\text { Sidedress } \\
\left(\mathrm{kg} \cdot \mathrm{ha}^{-1}\right)\end{array}$ \\
\hline Year $^{2}$ & 56 & --- \\
$1991-93$ & 56 & 7.2 \\
1994 & 33.6 & 5.6 \\
1995 & 33.6 & 11.2 \\
1996 & 33.6 & 11.2 \\
1997 & 33.6 & 5.6 \\
1998 &
\end{tabular}

${ }^{2}$ In all years, a $9 \mathrm{~N}-19.7 \mathrm{P}-12.4 \mathrm{~K}$ analysis soluble fertilizer was added to the transplant water at 3.9 $\mathrm{gm} \cdot \mathrm{L}^{-1}$ and applied at about $0.24 \mathrm{~L} /$ plant.

(Colletotrichum coccodes) (Pitblado, 1988), diseases common in New Jersey. Each system, as originally developed, uses specific decision thresholds - critical cumulative severity values determined by the disease risk models - to generate the disease forecast and resulting disease control schedule. PA-FAST initiates fungicide applications when cumulative total dew SV since transplant date $=35$ and plants are in the field for at least $28 \mathrm{~d}$. Subsequent applications are made when one of the following criteria are met: total dew SV for 7 consecutive days $\geq 13$ or total rain SV for $5 \mathrm{~d}$ $\geq 9$ and at least $7 \mathrm{~d}$ have passed since previous application; total dew SV for 7 consecutive d $\geq 13$ and total rain $\mathrm{SV}$ for 5 consecutive $\mathrm{d} \geq 9$ and at least $5 \mathrm{~d}$ have passed since previous application. CU-FAST initiates fungicide applications when cumulative total dew SV since transplant equal at least 30 and total dew SV for 7 consecutive $d \geq 12$ and/or total rain SV for 5 consecutive $d \geq 8$. Subsequent applications are made when one of the following criteria are met: total dew $\mathrm{SV}$ for 7 consecutive $\mathrm{d} \geq 12$ or total rain $\mathrm{SV}$ for 5 consecutive $\mathrm{d} \geq 8$ and at least $7 \mathrm{~d}$ have passed since previous application; total dew SV for 7 consecutive $\mathrm{d} \geq 12$ and total rain $\mathrm{SV}$ for 5 consecutive $\mathrm{d} \geq 8$ and at least $5 \mathrm{~d}$ have passed since previous application (1991) or at least $7 \mathrm{~d}$ have passed since previous application, applying fungicide as soon as possible (1992-95). TOM-CAST initiates applications when cumulative total dew SV since transplant $=35$. Subsequent applications are made when 20 dew SV accumulate since previous application.

Use of these forecast systems in locales other than where they were developed requires field evaluation in those areas. When compared in Massachusetts, TOM-CAST reduced fungicide applications more than CUFAST without reducing yield (Hazzard et al., 1992). A TOM-CAST schedule for fungicide application maintained fruit yield and quality with $40 \%$ fewer fungicide applications than the conventional schedule (Hazzard et al., 1994). In South Carolina, TOM-CAST scheduled applications maintained early blight control and yield with fungicide input reduced by nearly $50 \%$ (Keinath et al., 1996). Similar results were obtained in Maryland (Mills et al., 1999).

In 1988, concern that Rutgers Cooperative Extension's recommendations for early blight control in commercial tomato production were not appropriate for northern New Jersey led to trials that evaluated fungicide initiation timing for early blight control (Cowgill and Johnston, 1989; Cowgill et al., 1990). These trials included a modified PA-FAST system, NJ-FAST, that did not consider number of days plants were in the field after transplant in the decision to initiate fungicide applications. Results indicated that early blight might be controlled using a schedule based on NJ-FAST with fewer applications than required by a calendar-based schedule. Evaluation of early blight forecast systems began in 1991.

\section{Materials and Methods}

All trials from 1991-98 were conducted at the Rutgers Snyder Research and Extension Farm in Pittstown, N.J. The soil was a Quakertown silt loam (fine-loamy, mixed, mesic, Typic Hapludults). The 1991, 1992, and 1995-98 trials were single-factor experiments, the factor being disease control treatment. The 1993 and 1994 trails were factorial experiments, the factors being disease control treatment and culture. Data on foliar disease, yield and postharvest decay were collected.

Fertility. Nitrogen applications are given in Table 1. Phosphorous and potassium applications were based on annual soil test results and nutrient recommendations for tomato production from the New Jersey commercial vegetable recommendations that are published

Table2. Culture details for early blight forecasting trials, 1991-98.

\begin{tabular}{|c|c|c|c|c|c|c|}
\hline $\begin{array}{l}\text { Year/ } \\
\text { transplant } \\
\text { date }\end{array}$ & Cultivar & Culture & $\begin{array}{l}\text { Experimental } \\
\text { unit } \\
\text { (no. of plants) }\end{array}$ & $\begin{array}{l}\text { Row } \\
\text { spacing } \\
(\mathrm{m})\end{array}$ & $\begin{array}{l}\text { Plant } \\
\text { spacing } \\
\text { (m) }\end{array}$ & $\begin{array}{c}\text { Plant } \\
\text { population } \\
\text { (plants/ha) }\end{array}$ \\
\hline 1991/23 May & Celebrity & Bare ground; overhead irrigation; ground culture & 9 & 1.8 & 0.9 & 5,977 \\
\hline 1992/4 June & Celebrity & Bare ground; overhead irrigation; ground culture & 10 & 1.8 & 0.6 & 8,966 \\
\hline 1994/25 May & Celebrity & Raised bed; black plastic mulch; trickle irrigation; staked or ground culture & & & & \\
\hline 1995/25 May & Mountain Spring & Raised bed, black plastic mulch, trickle irrigation; staked culture & 10 & 1.8 & 0.5 & 11,955 \\
\hline 1996/10 June & Mountain Spring & Raised bed, black plastic mulch, trickle irrigation; staked culture & & & & \\
\hline
\end{tabular}

${ }^{2}$ Plants in single rows; alleyways separated the plots; guard rows established between and outside the treatment rows; single guard plants established at each end of the treatment plot.

Table 3. Early blight forecast systems and modifications evaluated, 1991-98.

\begin{tabular}{|c|c|c|c|}
\hline Forecast & Decisiol & thresholds & Year(s) \\
\hline system & Fungicide application initiation & Fungicide reapplication & evaluated \\
\hline CU-FAST & $\begin{array}{l}\text { At least } 30 \text { dew SV accumulated since transplant } \\
\text { date and reapplication dew or rain SV threshold met }\end{array}$ & $\begin{array}{l}\text { Dew } \mathrm{SV} \geq 12 / 7 \mathrm{~d} \text { or rain } \mathrm{SV} \geq 8 / 5 \mathrm{~d} \text { and at least } 7 \mathrm{~d} \text { since } \\
\text { application; dew } \mathrm{SV} \geq 12 / 7 \mathrm{~d} \text { and rain } \mathrm{SV} \geq 8 / 5 \mathrm{~d} \text { and at least } \\
\text { previous } 5 \mathrm{~d} \text { since previous application }(1991) \text { or apply as } \\
\text { soon as possible if } 7 \mathrm{~d} \text { since previous application }(1992-95)\end{array}$ & 1991-95 \\
\hline TOM-CAST 35-25 & 35 dew SV accumulated since transplant & 25 dew SV accumulated since previous application & 1994-96 \\
\hline TOM-CAST 25-15 & 25 dew SV accumulated since transplant & 15 dew SV accumulated since previous application & 1995-96 \\
\hline TOM-CAST 25-15+14 & 25 dew SV accumulated since transplant & $\begin{array}{l}15 \text { dew SV accumulated or } 14 \mathrm{~d} \text { since previous application, } \\
\text { which ever occurs first }\end{array}$ & 1995 \\
\hline TOM-CAST 25-25 & 25 dew SV & 25 dew SV accumulated since previous application & 1995-96 \\
\hline TOM-CAST 15-15 & 15 dew SV accumulated since transplant & 15 dew SV accumulated since previous application & 1995-96 \\
\hline TOM-CAST $15-25$ & 15 dew SV accumulated since transplant & 25 dew SV accumulated since previous application & 1995-96 \\
\hline
\end{tabular}

${ }^{2}$ Dew SV is daily disease severity value relating hours of leaf wetness and temperature during leaf wetness to disease risk.

${ }^{\mathrm{y}} \mathrm{Rain} \mathrm{SV}$ is daily disease severity rating values relating the five day average air temperature and relative humidity and seven day rainfall to disease risk. 
annually by Rutgers Cooperative Extension and the New Jersey Agricultural Experiment Station (Garrison, 2000).

Culture. Details for each year are given in Table 2. In all years, transplants were set in the field using a water wheel transplanter (model 1406; Kennco Mfg., Ruskin, Fla.). Stake culture plants were pruned three weeks after transplanting, leaving one axillary shoot below the first flower cluster, and staked and tied using the short-stake cultural system (Neary, 1992).

Forecast systems. Three forecast systems and modifications of those systems were evaluated from 1991-98 (Table 3). CU-FAST and TOM-CAST were evaluated using the original decision thresholds. NJ-FAST and several modifications of TOM-CAST, designated TOM-CAST 35-15, TOM-CAST 35-25, TOM-CAST 25-15, TOM-CAST 25-15+14, TOM-CAST 25-25, TOM-CAST 15-15, TOM-CAST 15-25 and TOM-CAST 25-15 to 20 , were also evaluated. Weather data for generating disease forecasts was collected onsite with a Weathertronics hygrothermograph (model 5020A; Qualimetrics, Inc., Sacramento, Calif.) in 1991. From 1992-94, weather data was collected on-site with a datalogger (21X; Campbell Scientific, Logan, Utah). One flat, printed circuit leaf wetness sensor (model 237; Campbell Scientific, Logan, Utah) was installed at the top of the tomato canopy (1992-93) and about $15 \mathrm{~cm}$ above mowed turf (1994). Leaf wetness was recorded every $30 \mathrm{~s}$ and reported as total minutes wet per 30 minute interval. From 1995-98, weather data was collected on site with a field monitor (Sensor Instruments, Inc., Concord, N.H.). One flat, printed circuit leaf wetness sensor (Sensor Instruments) was placed at the top of the tomato canopy in 1995 and about 15 $\mathrm{cm}$ above mowed turf in 1996-98. Leaf wetness was recorded every $60 \mathrm{~s}$ and reported as total minutes wet per hour. The sensors were always installed facing north at a $45^{\circ}$ angle to horizontal. Criteria used to determine leaf wetness were based on manufacturer's recommendations. Sensor Instruments leaf wetness sensors were assumed to be wet when the resistance across the sensor fell below 2.2 mohm. Campbell Instruments leaf wetness sensors were calibrated in accordance with the field calibration procedure outlined in Campbell Instruments' manual for the model 237 leaf wetness sensor (Campbell Scientific, Inc., 1996). In this procedure, the threshold for establishing leaf wetness is determined by observing the vegetation, and noting the resistance of the sensor at the point when the leaves on the vegetation become wet.

Fungicides. The fungicides evaluated during trials from 1991-98 were chlorothalonil [Bravo 720 (1991-97), Bravo Weatherstik (1998), Syngenta Crop Protection, Inc., Greensboro, N.C.]; tribasic copper sulfate with sulfur (TopCop with Sulfur, StollerEnterprises, Inc., Houston, Texas); copper hydroxide (Champ Formula 2F, Nufarm, Chicago, Ill.; NuCop 3L, Micro Flo Co., Lakeland, Fla.); mancozeb (Manzate 200DF, Griffen LLC, Valdosta, Ga.); and azoxystrobin (Quadris,
Syngenta Crop Protection, Inc. Greensboro. N.C.). Applications were made with an Echo motorized backpack sprayer (model SHR2100; Echo, Inc., Lake Zurich, Ill.) delivering 937.5 L'ha' ${ }^{-1}$ (1991 and 1992) or $750 \mathrm{~L} \cdot \mathrm{ha}^{-1}$ (1993 and 1994). Applications in 1995-98 were made with a $\mathrm{CO}_{2}$ backpack boom sprayer (assembled by Rutgers Snyder Farm personnel) delivering $628.1 \mathrm{~L} \cdot \mathrm{ha}^{-1}$.

Disease assessment and yield determination. Foliar disease damage was rated by visually estimating the percent necrotic tomato foliage in each plot. Early blight was the most prevalent disease in most years, but other diseases were also present. Foliar disease rating was an estimate of necrotic foliage due to all diseases. In 1991 and 1992, ratings were done once in September. In 1993-98, ratings were done weekly, beginning with the first appearance of disease damage. In 1993-98, fruit showing at least some overall pink were harvested weekly, graded for marketable quality and weighed. In 1993-97, up to $11.34 \mathrm{~kg}$ of the graded and weighed marketable fruit was randomly selected, packed in 11.34-kg tomato boxes and stored for $6 \mathrm{~d}$ at 15.6 or $21.1^{\circ} \mathrm{C}$ and evaluated for decay.

Experimental design and analysis. A randomized complete block design with four replications was used in 1991, 1992 and 1995-98 to evaluate disease control treatments. In 1993 and 1994, a randomized complete block split plot design was used to evaluate disease control treatments and stake or ground culture. All data were subjected to appropriate analysis of variance using a computer program created by Jack Springer (Rutgers University), SuperAnova (Abacus Concepts, Inc., Berkely, Calif.) or SAS Statistical Program (SAS Institute, Cary, N.C.). Means comparisons were by Duncan's multiple range test or Fisher's protected least significant difference.

\section{Results}

1991-98: A summary. Forecast systems consistently called for fewer fungicide applications than a weekly schedule initiated two weeks after transplant. The weekly schedule required 12 to 17 applications for a growing season while the forecast systems required 1 to 10 applications (Table 4). With few exceptions, the forecast scheduled applications reduced foliar disease rating compared to the untreated check and, in some cases, resulted in foliar disease ratings comparable to those with weekly treatment (Table 4). Fungicide applications, whether weekly or forecast scheduled, increased marketable yield in only 2 of the 6 years that yield data were collected. In those 2 years, marketable yields with forecast scheduled treatments were comparable to those with weekly treatment in many cases (Table 4). Some fungicides evaluated as alternatives to chlorothalonil with the NJ-TOM-CAST system reduced foliar disease rating as much as or more than forecast scheduled chlorothalonil treatment but not always as much as weekly applications of the particular fungicide (Table 4).

1991 to 1994: Evaluating forecast systems.
Early blight was the most prevalent foliar disease in the field trial plots. Septoria leaf spot was present in 1993 and 1994. Foliar disease ratings did not distinguish between damage due to these diseases. In 1993, below normal rainfall and a field with no recent solanaceous crop history contributed to low disease pressure. Yield data were not collected in 1991 and 1992 but were collected in 1993 and 1994. Data on foliar disease, postharvest losses and yield from the 1993 and 1994 split plot trials were averaged across cultural treatment each year since there were no significant cultural system $x$ disease control treatment interactions. Results from these trials related to disease forecasting and cultural system have been reported (Tietjen et al., 2001).

Weekly chlorothalonil treatments reduced foliar disease rating compared to the untreated check in all years (Tables 5 and 6 ; Tietjen et al., 2001), and marketable yield was increased and postharvest loss to anthracnose decreased compared to the untreated check in 1994. All forecast schedules, except NJ-FAST in 1991, required fewer fungicide applications than any weekly schedule.

NJ-FAST scheduled chlorothalonil treatments reduced foliar disease rating compared to the untreated check in 3 of the 4 years and was as effective as weekly treatment initiated 2 weeks after transplanting in two of four years (Tables 5 and 6 and Tietjen et al., 2001). In 1994, marketable yield was increased compared to the untreated check but was less than yield with weekly treatment. Postharvest loss to anthracnose was the same as the untreated check and the weekly treatment .

CU-FAST scheduled chlorothalonil treatments reduced foliar disease rating compared to the untreated check in all years and were as effective as weekly treatments initiated 2 weeks after transplant (Tables 5 and 6 and Tietjen et al., 2001). Marketable yield and postharvest fruit loss to anthracnose was the same as with weekly treatment in 1994. Weekly and CUFAST scheduled copper sulfate with sulfur treatments were not as effective as comparable chlorothalonil treatments in reducing foliar disease rating in 1992 but were as effective in 1993.

Chlorothalonil applied on TOM-CAST schedules, whether using the original reapplication decision threshold of 20 dew SV or modified threshold of 15 or 25 dew SV, reduced foliar disease rating compared to the untreated check in 2 of 3 years but was not as effective as weekly applications (Table 6 and Tietjen et al., 2001). Marketable yield was increased compared to the untreated check and was the same as that with weekly treatment for two versions of the forecast system; loss to anthracnose was the same as the untreated check.

In 1991 and 1992, foliar disease ratings did not differ among the forecast scheduled chlorothalonil treatments (Tables 5 and 6). In 1993, the CU-FAST scheduled chlorothalonil treatments reduced disease rating more than NJ-FAST and TOM-CAST scheduled treatments, whose ratings did not differ. In 1994, CU-FAST and two versions of TOM-CAST reduced disease rating and increased marketable 
Table 4. Summary of foliar disease rating and marketable yield for early blight forecasting trials 1991-98, selected data ${ }^{\mathrm{z}}$.

\begin{tabular}{|c|c|c|c|c|c|c|c|c|c|c|}
\hline \multirow{2}{*}{$\begin{array}{l}\text { Treatment }^{\mathrm{y}} \\
\text { (fungicide) } \\
\text { (schedule) } \\
\text { Forecast system evaluation 1991-94 }\end{array}$} & \multicolumn{2}{|c|}{$\begin{array}{l}\text { Fungicide } \\
\text { applications } \\
\text { (no.) }\end{array}$} & \multicolumn{6}{|c|}{$\begin{array}{l}\text { Foliar } \\
\text { disease } \\
\text { rating }\end{array}$} & \multicolumn{2}{|c|}{$\begin{array}{c}\text { Marketable yield }{ }^{\text {wu }} \\
\text { (no. } 11.3 \mathrm{~kg} \\
\text { boxes/ha) }\end{array}$} \\
\hline & 1991 & 1992 & 1993 & 1994 & $1991^{\text {ut }}$ & $1992^{\text {ut }}$ & $1993^{\mathrm{sv}}$ & $1994^{\mathrm{sv}}$ & 1993 & 1994 \\
\hline Untreated check & 0 & 0 & 0 & 0 & $8.8 \mathrm{~b}$ & $10.0 \mathrm{~b}$ & $3.9 \mathrm{~b}$ & $5.4 \mathrm{~d}$ & 2238 & $3604 \mathrm{a}$ \\
\hline \multicolumn{11}{|l|}{ Chlorothalonil } \\
\hline Weekly & 12 & 14 & 14 & 14 & $2.2 \mathrm{a}$ & $6.3 \mathrm{a}$ & $3.0 \mathrm{a}$ & $3.3 \mathrm{a}$ & 2495 & $5445 \mathrm{c}$ \\
\hline NJ-FAST & 9 & 8 & 2 & 5 & $3.4 \mathrm{a}$ & $6.5 \mathrm{a}$ & $3.6 \mathrm{~b}$ & $4.4 \mathrm{c}$ & 2713 & $4554 \mathrm{~b}$ \\
\hline CU-FAST & 6 & 7 & 7 & 10 & $3.2 \mathrm{a}$ & $6.0 \mathrm{a}$ & $2.9 \mathrm{a}$ & $3.6 \mathrm{ab}$ & 2119 & $5207 \mathrm{c}$ \\
\hline TOM-CAST 35-20 & $--^{r}$ & 3 & 1 & 5 & --- & $6.5 \mathrm{a}$ & $3.9 \mathrm{~b}$ & $4.0 \mathrm{bc}$ & 2356 & $4554 \mathrm{~b}$ \\
\hline LSD & & & & & --- & --- & 0.5 & 0.4 & NS & 594 \\
\hline TOM-CAST Modification 1995-96 & 1995 & 1996 & & & $1995^{\mathrm{sv}}$ & $1996^{\mathrm{sv}}$ & & & 1995 & 1996 \\
\hline Untreated check & 0 & 0 & & & $5.0 \mathrm{~d}$ & $5.5 \mathrm{c}$ & & & 2554 & $1366 \mathrm{a}$ \\
\hline \multicolumn{11}{|l|}{ Chlorothalonil } \\
\hline Weekly & 16 & 13 & & & $2.8 \mathrm{a}$ & $3.5 \mathrm{a}$ & & & 2416 & $1921 \mathrm{~b}$ \\
\hline TOM-CAST 15-15 & 5 & 10 & & & $3.5 \mathrm{bc}$ & $3.5 \mathrm{a}$ & & & 2515 & $2336 \mathrm{bc}$ \\
\hline TOM-CAST 15-25 & 4 & 6 & & & $3.5 \mathrm{bc}$ & $4.8 \mathrm{~b}$ & & & 2455 & $1960 \mathrm{~b}$ \\
\hline TOM-CAST 25-15 & 5 & 9 & & & $3.3 \mathrm{ab}$ & $4.0 \mathrm{a}$ & & & 2614 & $2534 \mathrm{c}$ \\
\hline TOM-CAST 25-25 & 4 & 5 & & & $3.3 \mathrm{ab}$ & $4.0 \mathrm{a}$ & & & 2574 & $2000 \mathrm{~b}$ \\
\hline TOM-CAST 35-15 & 5 & 9 & & & $4.0 \mathrm{c}$ & $3.8 \mathrm{a}$ & & & 2713 & $1742 \mathrm{ab}$ \\
\hline TOM-CAST 35-25 & 3 & --- & & & $3.8 \mathrm{bc}$ & --- & & & 2574 & --- \\
\hline LSD & & & & & 0.7 & 0.6 & & & NS & 436 \\
\hline \multicolumn{11}{|l|}{ TOM-CAST verification and fungicide } \\
\hline Untreated check & 0 & 0 & & & $6.0 \mathrm{~d}$ & $6.0 \mathrm{e}$ & & & 2634 & $3346 \mathrm{bc}$ \\
\hline \multicolumn{11}{|l|}{ Chlorothalonil } \\
\hline Weekly & 17 & 15 & & & $3.8 \mathrm{~b}$ & $3.0 \mathrm{c}$ & & & 3109 & $3346 \mathrm{bc}$ \\
\hline NJ-TOM-CAST & 5 & 5 & & & $4.3 \mathrm{bc}$ & $4.0 \mathrm{~d}$ & & & 2614 & $3623 \mathrm{bc}$ \\
\hline \multicolumn{11}{|l|}{ Copper hydroxide } \\
\hline Weekly & 17 & 15 & & & $3.0 \mathrm{a}$ & $3.0 \mathrm{c}$ & & & 2594 & $2178 \mathrm{a}$ \\
\hline NJ-TOM-CAST & 5 & 5 & & & $4.5 \mathrm{c}$ & $4.0 \mathrm{~d}$ & & & 2871 & $3247 \mathrm{~b}$ \\
\hline \multicolumn{11}{|l|}{ Mancozeb/chlorothalonil } \\
\hline Weekly & 17 & 15 & & & $4.0 \mathrm{bc}$ & $3.3 \mathrm{c}$ & & & 2673 & $3307 \mathrm{bc}$ \\
\hline NJ-TOM-CAST & 5 & 5 & & & $4.3 \mathrm{bc}$ & $4.0 \mathrm{~d}$ & & & 2535 & $3920 \mathrm{c}$ \\
\hline \multicolumn{11}{|l|}{ Azoxystrobin or chlorothalonil } \\
\hline Weekly & 17 & 15 & & & --- & $1.8 \mathrm{a}$ & & & --- & $3722 \mathrm{bc}$ \\
\hline NJ-TOM-CAST & 5 & 5 & & & --- & $2.3 \mathrm{~b}$ & & & --- & $3663 \mathrm{bc}$ \\
\hline LSD & & & & & 0.56 & 0.50 & & & NS & 673 \\
\hline
\end{tabular}

${ }^{2}$ For complete data see Tables 5 to 10 and Tietjen et al., 2001.

${ }^{y}$ Chlorothalonil in 1991-96 is Bravo 720, $1.7 \mathrm{~kg} \cdot \mathrm{ha}^{-1}$ a.i.; in 1997 is Bravo 720, $2.5 \mathrm{~kg} \cdot \mathrm{ha}^{-1}$ a.i.; in 1998 is Bravo Weatherstik, $2.5 \mathrm{~kg} \cdot h \mathrm{~F}^{-1}$ a.i.; copper hydroxide is Champ 2F, $0.96 \mathrm{~kg} \cdot$ ha $^{-1}$ a.i. to $1.61 \mathrm{~kg} \cdot \mathrm{ha}^{-1}$ a.i; mancozeb/chlorothalonil is Manzate $200 \mathrm{DF}, 2.52 \mathrm{~kg} \cdot \mathrm{ha}^{-1}$ a.i; switching to Bravo $720,1.7 \mathrm{~kg} \cdot \mathrm{ha}^{-1} \mathrm{a} . \mathrm{i}$ when first fruit was one-third full size; azoxystrobin or chlorothalonil is Quadris $0.11 \mathrm{~kg} \cdot \mathrm{ha}^{-1}$ a.i alternating with Bravo $720,1.7 \mathrm{~kg} \cdot \mathrm{ha} \mathrm{a}^{-1} \mathrm{a} \cdot \mathrm{i}$, beginning with Bravo, maximum six Quadris applications. Weekly means fungicide applied weekly beginning 2 weeks after transplant; NJ-FAST means fungicide application initiated when 35 dew SV accumulated since transplant date; reapplication when dew $\mathrm{SV} \geq 13 / 7 \mathrm{~d}$ or rain $\mathrm{SV} \geq 9 / 5 \mathrm{~d}$ and at least $7 \mathrm{~d}$ since previous application, or dew $\mathrm{SV} \geq 13$ and rain $\mathrm{SV} \geq 9$ and at least $5 \mathrm{~d}$ since previous application; CU-FAST means fungicide application initiated when at least 30 dew SV accumulated since transplant date and dew or rain SV threshold met; reapplication when dew $\mathrm{SV} \geq 12 / 7 \mathrm{~d}$ or rain $\mathrm{SV} \geq 8 / 5 \mathrm{~d}$ and at least $7 \mathrm{~d}$ since previous application, or dew $\mathrm{SV} \geq 12 / 7$ days and rain $S V \geq 8 / 5 \mathrm{~d}$ and at least $5 \mathrm{~d}$ since previous application (1991) or apply as soon as possible if $7 \mathrm{~d}$ since previous application (1992-95). TOM-CAST means fungicide application initiated when 35 dew SV accumulated since transplant; reapplication when 20 dew SV accumulated since previous application; TOM-CAST 35-15 means fungicide application initiated when 35 dew SV accumulated since transplant; reapplication when 15 dew SV accumulated since previous application; TOM-CAST 35-20 means fungicide application initiated when 35 dew SV accumulated since transplant; reapplication when 20 dew SV accumulated since previous application; TOM-CAST 35-25 means fungicide application initiated when 35 dew SV accumulated since transplant; reapplication when 25 dew SV accumulated since previous application; NJ-TOM-CAST means fungicide application initiated when 25 dew SV accumulated since transplant; reapplication when 15 to 20 dew SV accumulated since previous application.

${ }^{x}$ Estimates necrotic foliage due to all diseases. Diseases present were early blight, 1991-92; early blight and septoria leaf spot, 1993-95; early blight, septoria leaf spot and bacterial speck, 1996; early blight, powdery mildew, bacterial speck and bacterial canker, 1997-98.

${ }^{\text {wFruit }} \geq 6.4 \mathrm{~cm}$ diameter, uniform shape and free of defects.

'Means separation in column by Fisher's least significant difference, $P=0.05$; means followed by the same letter are not significantly different.

"Visual rating of $\%$ necrotic foliage (12 Sept. 1991, 15 Sept. 1992) using a ten class scale: 1 is $0 \% \leq 10 \%, 2$ is $>10 \% \leq 20 \%, 3$ is $>20 \% \leq 0 \%, 4$ is $>30 \% \leq$ $40 \%, 5$ is $>40 \% \leq 50 \%, 6$ is $>50 \% \leq 60 \%, 7$ is $>60 \% \leq 70 \%, 8$ is $>70 \% \leq 80 \%, 9$ is $>80 \% \leq 90 \%, 10$ is $>90 \% \leq 100 \%$.

'Means separation in columns by Duncan's multiple range test, $P=0.05$; means followed by the same letter are not significantly different.

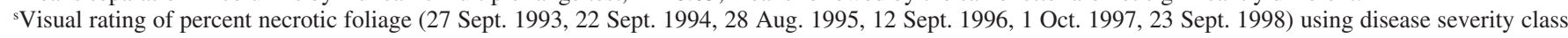
scale: 1 is $0 \%, 2$ is $\geq 1 \leq 10 \%, 3$ is $>10 \leq 30 \%, 4$ is $>30 \leq 70 \%, 5$ is $>70 \leq 90 \%, 6$ is $>90 \leq 100 \%$ (Dillard et al., 1997).

'Treatment not included in this year.

yield more that NJ-FAST, but only CU-FAST reduced postharvest fruit loss to anthracnose (Tietjen et al., 2001).

Results from the 1991-94 trials indicated that forecast-scheduled chlorothalonil applications could control early blight and septoria leaf spot, and the forecast schedules required fewer applications than a weekly schedule.
Although NJ-FAST and TOM-CAST scheduled chlorothalonil applications did not, in all instances, control foliar disease as well as CU-FAST or weekly scheduled treatments in 1993 and 1994, NJ-FAST and TOM-CAST schedules reduced the number of fungicide applications considerably and increased marketable yield compared to the untreated check in 1994. Increased postharvest loss in 1994, evident when comparing results for NJ-FAST and TOM-CAST schedules to weekly and CUFAST schedules, was of concern.

These trials also revealed important differences in ease of use among the forecast systems. TOM-CAST required monitoring only hours of leaf wetness and temperature during leaf 
wetness for generating the forecast, and the decision-making calculations could be done manually. NJ-FAST and CU-FAST required monitoring relative humidity and rainfall, in addition to leaf wetness and temperature. Use of computer software was a practical necessity for generating forecasts with NJ-FAST and CU-FAST. Anticipating that cost of equipment and ease of use, in addition to effectiveness, could influence grower adoption of disease forecasting, the 1995-98 trials focused on the TOM-CAST system and improving disease control, particularly of postharvest decays, by modifying the decision thresholds.

1995 and 1996: TOM-CAST modification. Early blight was the most prevalent foliar fungal disease and septoria leaf spot was also present in both years. Bacterial speck (PSeudomonas syringae pv. Tomato) was present in 1996. Foliar disease ratings did not distinguish among damage due to these diseases. All treatments reduced foliar disease rating compared to the untreated check in both years, and forecast schedules required fewer applications than the weekly schedule (Tables 7 and 8). There was no significant difference in marketable yield (Table 7), postharvest loss, or loss due to anthracnose (data not shown) among treatments in 1995. All fungicide treatments reduced postharvest loss in 1996 (Table 8).

Only TOM-CAST 25-15 and TOM-CAST 25-25 scheduled treatments reduced foliar disease rating as much as weekly treatments in both years (Tables 7 and 8). Marketable yield was increased and postharvest loss decreased compared to the untreated check in 1996. Marketable yield was the same as or higher than that with the weekly schedule and postharvest loss was less than that with the weekly schedule (Table 8). Adding a $14 \mathrm{~d}$ default for reapplication to a TOM-CAST 25-15 schedule (TOM-CAST 25-15+14) increased the number of applications by two but did not improve foliar disease control (Table 7).
With the exception of TOM-CAST 35-15 in 1995 and TOM-CAST 15-25 in 1996, there were no differences in foliar disease rating among TOM-CAST scheduled chlorothalonil treatments in either year. There were no differences in marketable yields among TOMCAST scheduled chlorothalonil treatments in 1996, with the exception of the TOM-CAST 25-15 schedule (Table 8). Weekly or TOMCAST scheduled copper hydroxide treatments reduced foliar disease rating and postharvest loss compared to the untreated check, but the TOM-CAST scheduled treatment was not as effective as the weekly treatment in reducing foliar disease rating and increasing marketable yield (Table 8)

Based on results from 1992-96, the decision thresholds for using TOM-CAST in northern New Jersey were chosen and the forecast system designated NJ-TOM-CAST. Fungicide applications would be initiated at 25 dew SV since applications initiated later than 25 dew

Table 5. Effect of disease control treatment on foliar disease of fresh-market tomato 'Celebrity'treated with chlorothalonil ${ }^{2}, 1991$.

\begin{tabular}{|c|c|c|c|}
\hline $\begin{array}{l}\text { Treatment }^{\mathrm{y}} \\
\text { (fungicide) } \\
\text { (schedule) }\end{array}$ & $\begin{array}{l}\text { Fungicide } \\
\text { initiation } \\
\text { (weeks } \\
\text { after } \\
\text { transplant) }\end{array}$ & $\begin{array}{c}\text { Fungicide } \\
\text { applications } \\
\text { (no.) }\end{array}$ & $\begin{array}{l}\text { Foliar } \\
\text { disease } \\
\text { rating }\end{array}$ \\
\hline Untreated check & --- & 0 & $8.8 \mathrm{~b}$ \\
\hline Weekly & 0 & 14 & $2.5 \mathrm{a}$ \\
\hline Weekly & 2 & 12 & $2.2 \mathrm{a}$ \\
\hline Weekly & 4 & 10 & $2.8 \mathrm{a}$ \\
\hline Weekly & 6 & 8 & $3.2 \mathrm{a}$ \\
\hline NJ-FAST & 4.7 & 9 & $3.4 \mathrm{a}$ \\
\hline CU-FAST & 4.7 & 6 & $3.2 \mathrm{a}$ \\
\hline
\end{tabular}

${ }^{\text {zBravo } 720,1.7 \mathrm{~kg} \cdot \mathrm{ha}^{-1} \text { a.i. }}$

${ }^{y}$ Weekly means fungicide applied weekly after initial application; NJ-FAST means fungicide application initiated when 35 dew SV accumulated since transplant date; reapplication when dew $\mathrm{SV} \geq 13 / 7 \mathrm{~d}$ or rain $\mathrm{SV} \geq 9 / 5 \mathrm{~d}$ and at least $7 \mathrm{~d}$ since previous application, or dew $\mathrm{SV} \geq 13$ and rain $\mathrm{SV} \geq 9$ and at least $5 \mathrm{~d}$ since previous application; CU-FAST means fungicide application initiated when at least 30 dew SV accumulated since transplant date and dew or rain SV threshold met; reapplication when dew $\mathrm{SV} \geq 12 / 7 \mathrm{~d}$ or rain $\mathrm{SV} \geq 8 / 5 \mathrm{~d}$ and at least $7 \mathrm{~d}$ since previous application, or dew $\mathrm{SV} \geq 12 / 7 \mathrm{~d}$ and rain $\mathrm{SV} \geq 8 / 5 \mathrm{~d}$ and at least 5 d since previous application.

${ }^{x}$ Visual rating of $\%$ necrotic foliage ( 12 Sept.) using a 10 class scale: 1 is $0 \% \leq 10 \%, 2$ is $>10 \% \leq 20 \%, 3$ is $>20 \% \leq 0 \%, 4$ is $>30 \%<40 \%, 5$ is $>40 \%<50 \%$, 6 is $>50 \% \leq 60 \%, 7$ is $>60 \% \leq 70 \%, 8$ is $>70 \% \leq 80 \%, 9$ is $>80 \% \leq 90 \%, 10$ is $>90 \% \leq 100 \%$. Disease present was early blight.

${ }^{\text {w}}$ Means separation in columns by Duncan's multiple range test, $P=0.05$; means followed by the same letter are not significantly different.

Table 6. Effect of disease control treatment on foliar disease of fresh-market tomato 'Celebrity', 1992.

\begin{tabular}{|c|c|c|c|}
\hline $\begin{array}{l}\text { Treatment }^{z} \\
\text { (fungicide) } \\
\text { (schedule) }\end{array}$ & $\begin{array}{l}\text { Fungicide } \\
\text { initiation } \\
\text { (weeks } \\
\text { after } \\
\text { transplant) }\end{array}$ & $\begin{array}{c}\text { Fungicide } \\
\text { applications } \\
\text { (no.) }\end{array}$ & $\begin{array}{l}\text { Foliar } \\
\text { disease } \\
\text { rating }\end{array}$ \\
\hline Untreated check & --- & 0 & $10.0 \mathrm{~d}$ \\
\hline \multicolumn{4}{|l|}{ Chlorothalonil } \\
\hline Weekly & 0 & 14 & $4.0 \mathrm{a}$ \\
\hline Weekly & 2 & 12 & $6.3 \mathrm{~b}$ \\
\hline Weekly & 4 & 10 & $4.0 \mathrm{a}$ \\
\hline Weekly & 6 & 8 & $4.5 \mathrm{a}$ \\
\hline NJ-FAST & 8 & 6 & $6.5 \mathrm{~b}$ \\
\hline CU-FAST & 7 & 6 & $6.0 \mathrm{~b}$ \\
\hline TOM-CAST & 10 & 3 & $6.5 \mathrm{~b}$ \\
\hline \multicolumn{4}{|c|}{ Tribasic copper sulfate with sulfur } \\
\hline Weekly & 0 & 14 & $8.0 \mathrm{c}$ \\
\hline CU-FAST & 7 & 6 & $9.3 \mathrm{~d}$ \\
\hline
\end{tabular}

${ }^{2}$ Chlorothalonil is Bravo 720, $1.7 \mathrm{~kg} \cdot \mathrm{ha}^{-1}$ a.i.; tribasic copper sulfate with sulfur is TopCop with Sulfur, $0.7 \mathrm{~kg} \cdot \mathrm{ha}^{-1}$ a.i. with $4.4 \mathrm{~kg} \cdot \mathrm{ha}^{-1}$ a.i. Weekly means fungicide applied weekly after initial application; NJ-FAST means fungicide application initiated when 35 dew SV accumulated since transplant date; reapplication when dew $\mathrm{SV} \geq 13 / 7 \mathrm{~d}$ or rain $\mathrm{SV} \geq 9 / 5 \mathrm{~d}$ and at least $7 \mathrm{~d}$ since previous application, or dew $\mathrm{SV} \geq 13$ and rain $\mathrm{SV} \geq 9$ and at least $5 \mathrm{~d}$ since previous application; CU-FAST means fungicide application initiated when at least 30 dew SV accumulated since transplant date and dew or rain SV threshold met; reapplication when dew $\mathrm{SV} \geq 12 / 7 \mathrm{~d}$ or rain $\mathrm{SV} \geq 8 / 5 \mathrm{~d}$ and at least $7 \mathrm{~d}$ since previous application, or dew $\mathrm{SV} \geq 12 / 7 \mathrm{~d}$ and rain $\mathrm{SV} \geq 8 / 5 \mathrm{~d}$ apply as soon as possible if $7 \mathrm{~d}$ since previous application. TOM-CAST means fungicide application initiated when 35 dew SV accumulated since transplant; reapplication when 20 dew SV accumulated since previous application.

${ }^{\mathrm{y}}$ Visual rating of $\%$ necrotic foliage ( 15 Sept.) using a ten class scale: 1 is $0 \% \leq 10 \%, 2$ is $>10 \% \leq 20 \%, 3$ is $>20 \% \leq 0 \%, 4$ is $>30 \% \leq 40 \%, 5$ is $>40 \% \leq 50 \%$, 6 is $>50 \leq 60 \%, 7$ is $>60 \% \leq 70 \%, 8$ is $>70 \% \leq 80 \%, 9$ is $>80 \% \leq 90 \%, 10$ is $>90 \% \leq 100 \%$. Disease present was early blight.

${ }^{x}$ Mean separation in columns by Duncan's multiple range test, $P=0.05$; means followed by the same letter are not significantly different. 
SV had not provided adequate control of early blight and other foliar disease, and there was no advantage to initiating applications sooner than 25 dew SV. A range of 15 to 20 dew SV accumulated since the previous application was designated as the reapplication interval although a 25 dew SV interval was shown to be adequate for controlling foliar diseases and fruit decay. A 15 to 20 dew SV range would provide a margin of flexibility in using $\mathrm{NJ}$ TOM-CAST and protect against exceeding a 25 dew SV reapplication interval since larger intervals were not evaluated. Verification of these decision thresholds and testing the efficacy of alternative fungicides with NJTOM-CAST were the focus of trials in 1997 and 1998.

1997and 1998: NJ-TOM-CASTverification and fungicide evaluation. Disease pressure was high both years, and the principle diseases present were early blight, powdery mildew (Oidiopsis sicula), bacterial speck, and bacterial canker (Clavibacter michiganensis subsp. michiganensis) (1997). Foliar disease ratings did not distinguish among the damage due to these diseases. Some early season foliar damage attributed to environmental stress was also evident. Powdery mildew rating was based on mycelial growth visible on the foliage.

All treatments resulted in foliar disease ratings significantly lower than those of the untreated check. (Tables 9 and 10). Powdery mildew was also reduced by all treatments except NJ-TOM-CAST scheduled copper hydroxide (NuCop). The NJ-TOM-CAST schedule required 5 applications compared to 17 (1997) and 15 (1998) weekly applications. NJ-TOM-CAST scheduled treatment with chlorothalonil or chlorothalonil switching to mancozeb reduced foliar disease and powdery mildew ratings as much as the weekly scheduled treatment in 1997 but not in 1998. Neither weekly nor NJ-TOM-CAST scheduled applications of these fungicides increased marketable yield compared to the untreated check in either year (Tables 9and 10). Total postharvest loss and loss to anthracnose were the same for all treatments in 1997 (data not shown). Azoxystrobin alternating with chlorothalonil applied on a weekly or TOM-CAST schedule reduced foliar disease rating more than other treatments but did not affect marketable yield (Table 10). NJ-TOM-CAST scheduled copper hydroxide or copper hydroxide with chlorothalonil treatments did not reduce foliar disease rating as much as the weekly scheduled treatments in either year. They did not reduce powdery mildew as much as the weekly scheduled treatments in either year with one exception in 1997 (Table 9). NJ-TOM-CAST scheduled treatment with these materials did not affect marketable yield compared to the untreated check. Weekly applications of copper hydroxide (Champ) reduced marketable yield compared to all other treatments. The cause of this reduction is unknown.

\section{Discussion}

In field trials conducted from 1991-98, forecast scheduling of fungicide applications was shown to be a viable alternative to calendar-based scheduling for controlling early blight, septoria leaf spot and fruit anthracnose in northern New Jersey. The TOM-CAST system, found to be easier to use to generate forecasts and requiring less weather monitoring equipment than the NJ-FAST and CU-FAST systems, was modified to provide effective disease forecasts under local conditions. From 1995 through 1998, conservative TOM-CAST 25-15 or NJ-TOM-CAST schedules required on average 6 fungicide applications per year compared to weekly schedules that required on average 15 applications per year. This reduction of $61 \%$ was greater than those reported by others (Hazzard, 1994; Keinath, 1996; Mills et al., 1999; Pitblado, 1988). Reducing the number of fungicide applications using TOM-CAST 2515 or NJ-TOM-CAST had no adverse impact on marketable yields from 1995 to 1998. In 1995, 1997 and 1998, fungicide applications did not increase marketable yields compared

Table 7. Effect of disease control treatment on foliar disease and marketable yield of fresh-market tomato 'Mountain Spring' treated with chlorothalonil z, 1995.

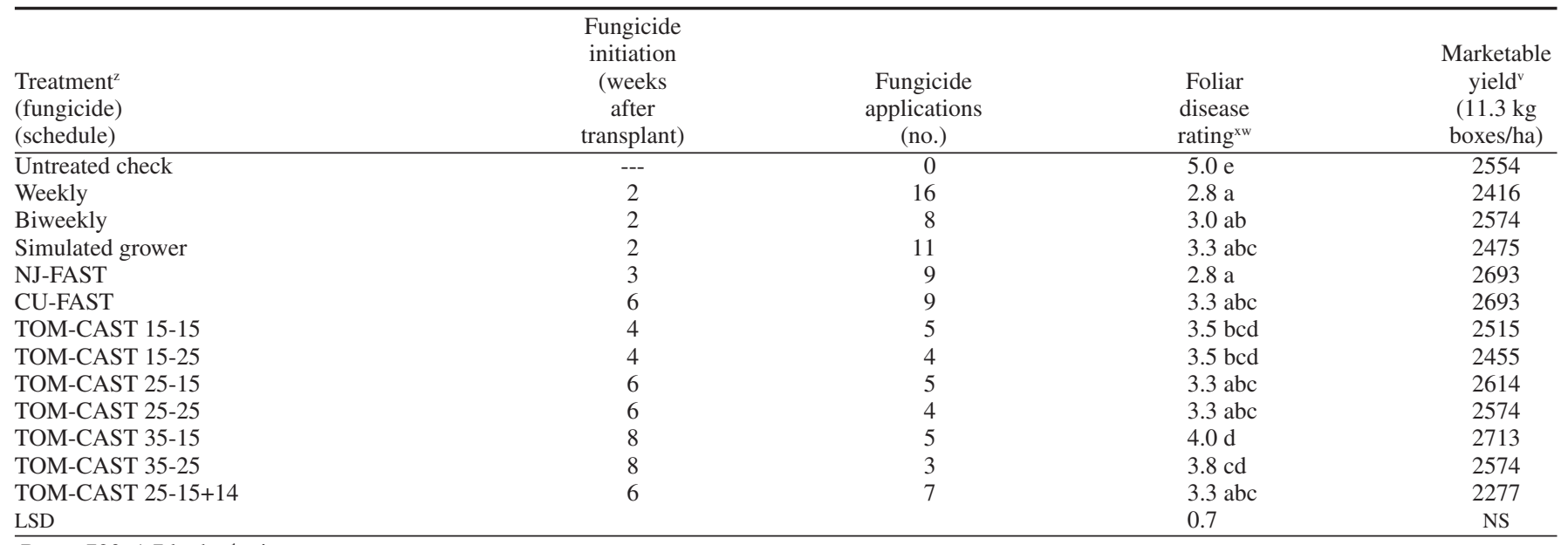

${ }^{2}$ Bravo $720,1.7 \mathrm{~kg} \cdot \mathrm{ha}^{-1}$ a.i.

${ }^{y}$ Weekly means fungicide applied weekly after initial application; biweekly means fungicide applied biweekly starting two weeks after transplant; simulated grower means fungicide applied two weeks after transplant with reapplication at 7-d interval if $>1$ but $<2$ inches rain since previous application, 10-d interval if $<1$ inch rain since previous application, or immediately if $>2$ inches rain since previous application; NJ-FAST means fungicide application initiated when 35 dew SV accumulated since transplant date; reapplication when dew SV $\geq 13 / 7 \mathrm{~d}$ or rain $\mathrm{SV} \geq 9 / 5 \mathrm{~d}$ and at least $7 \mathrm{~d}$ since previous application, or dew $\mathrm{SV} \geq 13$ and rain $\mathrm{SV} \geq 9$ and at least $5 \mathrm{~d}$ since previous application; CU-FAST means fungicide application initiated when at least 30 dew SV accumulated since transplant date and dew or rain SV threshold met; reapplication when dew SV $\geq 12 / 7 \mathrm{~d}$ or rain $\mathrm{SV} \geq 8 / 5 \mathrm{~d}$ and at least $7 \mathrm{~d}$ since previous application, or dew SV $\geq 12 / 7$ $\mathrm{d}$ and rain $\mathrm{SV} \geq 8 / 5 \mathrm{~d}$ apply as soon as possible if 7 days since previous application; TOM-CAST 15-15 means initiation when 15 dew SV accumulated since transplant; reapplication when 15 dew SV accumulated since previous application; TOM-CAST 15-25 means fungicide application initiated when 15 dew SV accumulated since transplant; reapplication when 25 dew SV accumulated since previous application; TOM-CAST 25-15 means fungicide application initiated when 25 dew SV accumulated since transplant; reapplication when 15 dew SV accumulated since previous application ; TOM-CAST 25-25 means fungicide application initiated when 25 dew SV accumulated since transplant; reapplication when 25 dew SV accumulated since previous application; TOM-CAST 35-15 means fungicide application initiated when 35 dew SV accumulated since transplant; reapplication when 15 dew SV accumulated since previous application; TOM-CAST 35-25 means fungicide application initiated when 35 dew SV accumulated since transplant; reapplication when 25 dew SV accumulated since previous application; TOM-CAST 25-15+14 means fungicide application initiated when 25 dew SV accumulated since transplant ; reapplication when 15 dew SV accumulated or 14 days since previous application, which ever occurs first.

${ }^{\mathrm{x}}$ Visual rating of percent necrotic foliage (28 Aug.) using disease severity class

scale: 1 is $0 \%, 2$ is $\geq 1 \% \leq 10 \%, 3$ is $>10 \% \leq 30 \%, 4$ is $>30 \% \leq 70 \%, 5$ is $>70 \% \leq 90 \%, 6$ is $>90 \% \leq 100 \%$ (Dillard et al., 1997). Diseases present were early blight and septoria leaf spot.

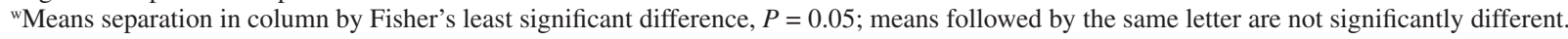

${ }^{v}$ Fruit $\geq 6.4 \mathrm{~cm}$ diameter, uniform shape and free of defects. 
Table 8. Effect of disease control treatment on foliar disease, postharvest loss and marketable yield of fresh-market tomato 'Mountain Spring', 1996.

\begin{tabular}{|c|c|c|c|c|c|}
\hline $\begin{array}{l}\text { Treatment }^{2} \\
\text { (fungicide) } \\
\text { (schedule) }\end{array}$ & $\begin{array}{l}\text { Fungicide } \\
\text { initiation } \\
\text { (weeks } \\
\text { after } \\
\text { transplant) }\end{array}$ & $\begin{array}{l}\text { Fungicide } \\
\text { applications } \\
\text { (no.) }\end{array}$ & $\begin{array}{l}\text { Foliar } \\
\text { disease } \\
\text { rating }\end{array}$ & $\begin{array}{c}\text { Postharvest } \\
\text { loss } \\
(\%)^{\mathrm{wv}}\end{array}$ & $\begin{array}{c}\text { Marketable } \\
\text { yield }{ }^{\mathrm{ux}} \\
(11.3 \mathrm{~kg} \\
\text { boxes } / \mathrm{ha})\end{array}$ \\
\hline \multicolumn{6}{|l|}{ Chlorothalonil } \\
\hline Weekly & 2 & 13 & $3.5 \mathrm{ab}$ & $11.5 \mathrm{~b}$ & $1,921 b$ \\
\hline Simulated grower & 2 & 9 & $3.5 \mathrm{ab}$ & $6.9 \mathrm{a}$ & $2,356 \mathrm{~cd}$ \\
\hline TOM-CAST 25-15 & 3 & 9 & $4.0 \mathrm{bc}$ & $6.0 \mathrm{a}$ & $2,534 \mathrm{~d}$ \\
\hline TOM-CAST 25-25 & 3 & 5 & $4.0 \mathrm{bc}$ & $8.9 \mathrm{a}$ & $2,000 \mathrm{bc}$ \\
\hline TOM-CAST 35-15 & 4.5 & 9 & $3.8 \mathrm{bc}$ & $7.7 \mathrm{a}$ & $1,742 \mathrm{ab}$ \\
\hline \multicolumn{6}{|l|}{ Copper hydroxide } \\
\hline Weekly & 2 & 13 & $3.0 \mathrm{a}$ & $7.2 \mathrm{a}$ & $1,921 \mathrm{~b}$ \\
\hline TOM-CAST 15-15 & 1.5 & 10 & $4.3 \mathrm{~cd}$ & $9.9 \mathrm{ab}$ & $1,445 \mathrm{a}$ \\
\hline LSD & & & 0.6 & --- & 436 \\
\hline
\end{tabular}

${ }^{2}$ Chlorothalonil is Bravo 720, $1.7 \mathrm{~kg} \cdot \mathrm{ha}^{-1}$ a.i.; copper hydroxide is Champ $2 \mathrm{~F}, 0.96 \mathrm{~kg} \cdot \mathrm{ha}^{-1}$ a.i. to $1.61 \mathrm{~kg} \cdot \mathrm{ha}^{-1}$ a.i. Weekly means fungicide applied weekly after initial application 2 weeks after transplant; simulated grower means fungicide applied 2 weeks after transplant with reapplication at 7 -d interval if $>1$ but $<2$ inches rain since previous application, 10 - $\mathrm{d}$ interval if $<1$ inch rain since previous application, or immediately if $>2$ inches rain since previous application; TOM-CAST 15-15 fungicide application initiated when 15 dew SV accumulated since transplant; reapplication when 15 dew SV accumulated since previous application; TOM-CAST 15-25 means fungicide application initiated when 15 dew SV accumulated since transplant; reapplication when 25 dew SV accumulated since previous application; TOM-CAST 25-15 means fungicide application initiated when 25 dew SV accumulated since transplant; reapplication when 15 dew SV accumulated since previous application; TOM-CAST 25-25 means fungicide application initiated when 25 dew SV accumulated since transplant; reapplication when 25 dew SV accumulated since previous application; TOM-CAST 35-15 means fungicide application initiated when 35 dew SV accumulated since transplant; reapplication when 15 dew SV accumulated since previous application.

${ }^{y}$ Visual rating of percent necrotic foliage (12 Sept.) using disease severity class

scale: 1 is $0 \%, 2$ is $\geq 1 \% \leq 10 \%, 3$ is $>10 \% \leq 30 \%, 4$ is $>30 \% \leq 70 \%, 5$ is $>70 \% \leq 90 \%, 6$ is $>90 \% \leq 100 \%$ (Dillard et al., 1997). Diseases present were early blight, Septoria leaf spot and bacterial speck.

${ }^{x}$ Means separation in column by Fisher's least significant difference, $P=0.05$; means followed by the same letter are not significantly different

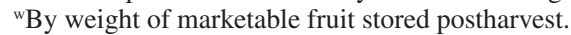

${ }^{\vee}$ Means separation by pair comparisons of least square means from SAS, $P=0.05$; LSD varied with sample size. Means followed by the same letter are not significantly different.

"Fruit $\geq 6.4 \mathrm{~cm}$ diameter, uniform shape and free of defects.

Table 9. Effect of disease control treatment on foliar disease of fresh-market tomato 'Mountain Spring', 1997.

\begin{tabular}{|c|c|c|c|c|c|}
\hline $\begin{array}{l}\text { Treatment }^{2} \\
\text { (fungicide) } \\
\text { (schedule) }\end{array}$ & $\begin{array}{l}\text { Fungicide } \\
\text { initiation } \\
\text { (weeks } \\
\text { after } \\
\text { transplant) }\end{array}$ & $\begin{array}{l}\text { Fungicide } \\
\text { applications } \\
\text { (no.) }\end{array}$ & $\begin{array}{l}\text { Foliar } \\
\text { disease } \\
\text { rating }\end{array}$ & $\begin{array}{l}\text { Powdery } \\
\text { mildew } \\
\text { rating }{ }^{\mathrm{xw}}\end{array}$ & $\begin{array}{c}\text { Marketable } \\
\text { yield }^{v} \\
(11.3 \mathrm{~kg} \\
\text { boxes } / \mathrm{ha})\end{array}$ \\
\hline \multicolumn{6}{|l|}{ Chlorothalonil } \\
\hline Weekly & 2 & 17 & $3.75 \mathrm{~cd}$ & $1.00 \mathrm{a}$ & 3109 \\
\hline Simulated grower & 2 & 13 & $3.75 \mathrm{~cd}$ & $1.00 \mathrm{a}$ & 2990 \\
\hline Weekly & 2 & 17 & 4.00 cde & $1.00 \mathrm{a}$ & 2673 \\
\hline NJ-TOM-CAST & 6 & 5 & $4.25 \mathrm{de}$ & $1.00 \mathrm{a}$ & 2535 \\
\hline \multicolumn{6}{|l|}{ Copper hydroxide } \\
\hline Weekly & 2 & 17 & $3.00 \mathrm{ab}$ & $1.00 \mathrm{a}$ & 2594 \\
\hline NJ-TOM-CAST & 6 & 5 & $4.50 \mathrm{e}$ & $1.75 \mathrm{~b}$ & 2871 \\
\hline \multicolumn{6}{|c|}{ Copper hydroxide with chlorothalonil } \\
\hline Weekly & 2 & 17 & $2.50 \mathrm{a}$ & $1.25 \mathrm{a}$ & 2832 \\
\hline
\end{tabular}

${ }^{2}$ Chlorothalonil is Bravo 720, $2.5 \mathrm{~kg} \cdot \mathrm{ha}^{-1}$ a.i.; mancozeb is Manzate $200 \mathrm{DF}, 2.52 \mathrm{~kg} \cdot h \mathrm{a}^{-1} \mathrm{a}$ a.i; mancozeb/chlorothalonil is Manzate switching to Bravo when first fruit was one-third full size; copper hydroxide is Champ $2 \mathrm{~F}, 0.96 \mathrm{~kg} \cdot \mathrm{ha}^{-1}$ a.i. to $1.61 \mathrm{~kg} \cdot \mathrm{ha}^{-1}$ a.i; copper hydroxide with chlorothalonil is Champ $2 \mathrm{~F}, 0.96 \mathrm{~kg} \cdot \mathrm{ha}^{-1}$ a.i. with Bravo $720,1.25 \mathrm{~kg} \cdot \mathrm{ha}^{-1}$ a.i.

Weekly means fungicide applied weekly after initial application 2 weeks after transplant; simulated grower means fungicide applied 2 weeks after transplant with reapplication at 7-d interval if $>1$ but $<2$ inches rain since previous application, 10-d interval if $<1$ inch rain since previous application, or immediately if $>2$ inches rain since previous application; NJ-TOM-CAST means initiation when 25 dew SV accumulated since transplant; reapplication when 15 to 20 dew SV accumulated since previous application.

${ }^{y}$ Visual rating of percent necrotic foliage (1 Oct.) using disease severity class scale: 1 is $0 \%, 2$ is $\geq 1 \% \leq 10 \%, 3$ is $>10 \% \leq 30 \%, 4$ is $>30 \% \leq 70 \%, 5$ is $>70 \%$ $\leq 90 \%, 6$ is $>90 \% \leq 100 \%$ (Dillard et al., 1997). Diseases present were early blight, powdery mildew, and bacterial speck.

${ }^{x}$ Mean separation in column by Fisher's least significant difference, $P=0.05$; means followed by the same letter are not significantly different.

${ }^{w}$ Visual rating of powdery mildew sign on foliage in plot (17 Sept.): 1 = no powdery fungal growth observed; 2 = some powdery fungal growth noticed with careful observation; 3 = powdery fungal growth easily observed on $<50 \%$ of foliage; $4=$ powdery fungal growth observed on most or all foliage.

${ }^{\vee}$ Fruit $\geq 6.4 \mathrm{~cm}$ diameter, uniform shape and free of defects.

to the untreated control, providing additional justification for reducing fungicide inputs by scheduling applications with NJ-TOM-CAST. NJ-TOM-CAST scheduled applications did in- crease marketable yield and reduce postharvest loss in 1996, confirming the benefit of fungicide use in some years. Others have reported no adverse effect of reducing number of fungicide applications on tomato yield (Hazzard, 1992, 1994; Keinath 1996; Mills, 1999) or no yield benefit from fungicide applications in some years (Brammall, 1993; Keinath et al., 1996; 


\begin{tabular}{|c|c|c|c|c|c|}
\hline $\begin{array}{l}\text { Treatment }^{2} \\
\text { (fungicide) } \\
\text { (schedule) }\end{array}$ & $\begin{array}{l}\text { Fungicide } \\
\text { initiation } \\
\text { (weeks } \\
\text { after } \\
\text { transplant) }\end{array}$ & $\begin{array}{l}\text { Fungicide } \\
\text { applications } \\
\text { (no.) }\end{array}$ & $\begin{array}{l}\text { Foliar } \\
\text { disease } \\
\text { ratingyx }\end{array}$ & $\begin{array}{l}\text { Powdery } \\
\text { mildew } \\
\text { rating }\end{array}$ & $\begin{array}{c}\text { Marketable } \\
\text { yield }^{v} \\
(11.3 \mathrm{~kg} \\
\text { boxes } / \mathrm{ha})\end{array}$ \\
\hline \multicolumn{6}{|l|}{ Chlorothalonil } \\
\hline Weekly & 2 & 15 & $3.0 \mathrm{c}$ & $1.3 \mathrm{a}$ & 3,346 bcde \\
\hline NJ-TOM-CAST & 4 & 5 & $4.0 \mathrm{de}$ & $2.3 \mathrm{bc}$ & 3,623 cde \\
\hline NJ-TOM-CAST & 4 & 5 & $2.3 \mathrm{~b}$ & $2.0 \mathrm{~b}$ & 3,663 cde \\
\hline \multicolumn{6}{|c|}{ Mancozeb/chlorothalonil } \\
\hline Weekly & 2 & 15 & $3.3 \mathrm{c}$ & $1.0 \mathrm{a}$ & 3,307 bcde \\
\hline NJ-TOM-CAST & 4 & 5 & $4.0 \mathrm{de}$ & $2.5 \mathrm{bcd}$ & $3,920 \mathrm{e}$ \\
\hline \multicolumn{6}{|l|}{ Copper hydroxide (C) } \\
\hline Weekly & 2 & 15 & $3.0 \mathrm{c}$ & $2.5 \mathrm{bcd}$ & $2,178 \mathrm{a}$ \\
\hline NJ-TOM-CAST & 4 & 5 & $4.0 \mathrm{de}$ & $3.3 \mathrm{ef}$ & $3,247 \mathrm{bcd}$ \\
\hline NJ-TOM-CAST & 4 & 5 & $5.0 \mathrm{f}$ & $3.8 \mathrm{fg}$ & $3,069 \mathrm{bcd}$ \\
\hline \multicolumn{6}{|c|}{ Copper hydroxide $(\mathrm{N})$ with chlorothalonil } \\
\hline Weekly & 2 & 15 & $3.0 \mathrm{c}$ & $1.0 \mathrm{a}$ & $3,227 \mathrm{bcd}$ \\
\hline NJ-TOM-CAST & 4 & 5 & $4.3 \mathrm{e}$ & $3.0 \mathrm{de}$ & 3,485 bcde \\
\hline LSD & & & 0.41 & 0.53 & 673 \\
\hline
\end{tabular}

${ }^{2}$ Chlorothalonil is Bravo Weatherstik, $2.5 \mathrm{~kg} \cdot \mathrm{ha}^{-1}$ a.i.; azoxystrobin is Quadris $0.11 \mathrm{~kg} \cdot \mathrm{ha}{ }^{-1}$ a.i; azoxystrobin or chlorothalonil is Quadris alternating with Bravo, beginning with Bravo, maximum six Quadris applications; mancozeb is Manzate $200 \mathrm{DF}, 2.52 \mathrm{~kg} \cdot \mathrm{ha}^{-1}$ a.i.; mancozeb/chlorothalonil is Manzate switching to Bravo when first fruit was one-third full size; copper hydroxide (C) is Champ 2F, $0.96 \mathrm{~kg} \cdot \mathrm{ha}^{-1}$ a.i. to $1.61 \mathrm{~kg} \cdot \mathrm{ha}{ }^{-1}$ a.i; copper hydroxide (C) with chlorothalonil is Champ 2F, $0.96 \mathrm{~kg} \cdot \mathrm{ha}^{-1}$ a.i. with Bravo, $1.25 \mathrm{~kg} \cdot \mathrm{ha}^{-1}$ a.i. copper hydroxide $(\mathrm{N})$ is NuCop $3 \mathrm{~L}, 0.96 \mathrm{~kg} \cdot \mathrm{ha}^{-1}$ a.i. to $1.61 \mathrm{~kg} \cdot \mathrm{ha} \mathrm{a}^{-1}$ a.i; copper hydroxide $(\mathrm{N})$ with chlorothalonil is Champ 2F, $0.96 \mathrm{~kg} \cdot \mathrm{ha}^{-1}$ a.i. with Bravo, $1.25 \mathrm{~kg} \cdot \mathrm{ha}^{-1}$ a.i. Weekly means fungicide applied weekly after initial application two weeks after transplant; NJ-TOM-CAST means fungicide applications initiated when 25 dew SV accumulated since transplant; reapplication when 15 to 20 dew SV accumulated since previous application.

${ }^{y}$ Visual rating of percent necrotic foliage (23 Sept.) using disease severity class scale: 1 is $0 \%, 2$ is $\geq 1 \% \leq 10 \%, 3$ is $>10 \% \leq 30 \%, 4$ is $>30 \% \leq 70 \%, 5$ is $>70 \%$ $\leq 90 \%, 6$ is $>90 \% \leq 100 \%$ (Dillard et al., 1997). Diseases present were early blight, powdery mildew, bacterial speck and bacterial canker.

${ }^{x}$ Means separation in column by Fisher's least significant difference, $P=0.05$; means followed by the same letter are not significantly different.

"Visual rating of powdery mildew sign on foliage in plot (17 Sept.): $1=$ no powdery fungal growth observed; $2=$ some powdery fungal growth noticed with careful observation; $3=$ powdery fungal growth easily observed on $<50 \%$ of foliage; 4 = powdery fungal growth observed on most or all foliage.

${ }^{v}$ Fruit $\geq 6.4 \mathrm{~cm}$ diameter, uniform shape and free of defects.

Louws, 1996; Poysa et al., 1993). Reducing the number of fungicide applications without reducing marketable yields would mean potential cost savings for growers and lower pesticide inputs to the environment.

Certain fungicides, in addition to chlorothalonil with which TOM-CAST was developed, were shown to maintain marketable yields when applied on the NJ-TOM-CAST schedule. Growers using NJ-TOM-CAST could use the lower cost mancozeb switching to chlorothalonil regimen or the new strobilurin fungicide, azoxystrobin, alternated with chlorothalonil. However, copper fungicides did not maintain marketable yield in all years when applied on a NJ-TOM-CAST schedule. This could limit the use of NJ-TOM-CAST by certified organic growers for whom copper fungicides are among the few allowed disease control materials.

The 1997 and 1998 trials provided a chance to address a general concern about the use of disease forecast systems: the potential increased vulnerability of the crop to diseases other than those for which the forecast system was developed. Bacterial diseases have been a particular concern in tomatoes (Gleason et al., 1995). In 1997, bacterial speck and bacterial canker were present in the research plots. Since foliar disease rating with NJ-TOM-CAST scheduled applications of chlorothalonil or mancozeb switching to chlorothalonil did not differ from rating with weekly applications, NJ-TOM-CAST scheduling did not result in increased foliar damage from bacterial disease (Table 9). Because bacterial disease was present, however, the best control of foliar disease was obtained with weekly applications of a fungicide with bactericidal action-copper hydroxide — or a combination of chlorothalonil and copper hydroxide. Copper hydroxide alone did not perform as well on the NJ-TOM-CAST schedule as on the weekly schedule. This may be attributed to reduced control of fungal diseases with copper fungicides, previously shown in 1992 and 1996, and to the impact of powdery mildew.

Powdery mildew, present in 1997 and 1998 and new on field grown tomatoes in New Jersey, was controlled by most treatments in 1997, but, in 1998, was not controlled as well by NJ-TOM-CAST-scheduled applications as by weekly applications. The disease was severe in both years, but the time between the last three NJ-TOM-CAST-scheduled applications was nearly 3 weeks in 1998 rather than about 2 weeks in 1997. This difference suggests that a default interval of a set number of days for reapplication might be an important addition to a forecast schedule to avoid extended time periods with no fungicide protection when the crop might be vulnerable to unanticipated diseases. In 1998, a 14-d application default would have added 2 applications to the 5 called for by NJ-TOM-CAST, the total still considerably less than the 15 weekly applications. The experience with powdery mildew affirms the importance of disease monitoring in the field in conjunction with use of NJ-TOM-CAST since controls for powdery mildew can be applied when disease first appears (Garrison, 2000).

Beginning in 1992, grower demonstration trials of disease forecasting and evaluations of site-specific weather data from the commercial weather service SkyBit, Inc. (Boalsburg, Pa.) were done concurrently with these research trials. Data collected at five sites in 1996 and six sites in 1997-99 showed that SkyBit-based forecasts called for, with one exception in one year, the same number of or more fungicide applications than on-site weather-based forecasts (M. Maletta, unpublished data). For 1997-99, onsite-data would have resulted in forecasts averaging 6 applications per season while SkyBit data would have resulted in forecasts averaging 8 applications per season (T. Manning, unpublished data). The SkyBit forecasts, though more conservative than onsite forecasts, would have reduced the average number of fungicide applications by $50 \%$ compared to a weekly application schedule. In 1999, NJ-TOM-CAST forecasts based on SkyBit data were offered to northern New Jersey tomato growers through the Rutgers 
Vegetable IPM Program. In 2000, through a cooperative effort of Rutgers Cooperative Extension and SkyBit, Inc., NJ-TOM-CAST became available from SkyBit, Inc. as an addon product with their commercial subscription weather service.

\section{Literature Cited}

Brammall, R.A. 1993. Effect of foliar fungicide treatment on early blight and yield of fresh-market tomato in Ontario. Plant Dis. 77:484-488.

Campbell Scientific, Inc. 1996. Model 237 leaf wetness sensor manual. Campbell Scientific.

Cowgill, W.P. and S.A. Johnston. 1989. Evaluation of fungicide initiation dates and a disease forecasting system for control of foliar diseases of tomato. N.J. Agr. Expt. Sta. Bul. 116.

Cowgill, W.P., M. Maletta, and S.A. Johnston. 1990. Evaluation of fungicide initiation dates and a disease forecasting system of control of foliar diseases of tomato. N.J. Agr. Expt. Sta. Bul. 117.

Dillard, H.R., S.A. Johnston, A.C. Cobb, and G.H. Hamilton. 1997. An assessment of fungicide benefits for the control of fungal diseases of processing tomatoes in New York and New Jersey. Plant Dis. 81:677-681.

Garrison, S.A. (ed.). 2000. Commercial vegetable production recommendations. N.J. Agr. Expt. Sta. Publ. E001P.
Gleason, M.L., A.A MacNab, R.E. Pitblado, M.D. Ricker, D.A. East, and R.X. Latin. 1995. Disease-warning systems for processing tomatoes in eastern North America: Are we there yet? Plant Dis. 79:113-121.

Hazzard, R., R. Wick, and T. Berry. 1992. Disease forecasting systems for control of early blight and septoria leaf spot in fresh-market tomatoes. Proc. VIII Annu. Tomato Dis. Wkshp., Columbus, Ohio, 3-4 Oct. 1992.

Hazzard, R., R. Wick, and M. Mazzola. 1994. TOMCAST forecasting system and cultural practices for managing early blight in fresh-market tomatoes. Proc. X Annu. Tomato Dis. Wkshp., East Lansing, Mich., 8-9 Dec. 1994.

Keinath, A.P. and V.A. DuBose. 1996. Efficacy and economics of three fungicide application schedules for early blight control and yield of freshmarket tomato. Plant Dis. 80:1277-1282.

Louws, F.J., M.K. Hausbeck, M.K. Kelly, and C.T. Stephens. 1996. Impact of reduced fungicide and tillage on foliar blight, fruit rot, and yield of processing tomatoes. Plant Dis. 80:1251-1256.

Madden, L., S.P. Pennypacker, and A.A. MacNab. 1978. FAST, a forecast system for Alternaria solani on tomato. Phytopathology 68:13541358.

MacNab, A.A. and S.P. Pennypacker. 1982. The "FAST" program for tomato early blight: Model description, program steps in BASIC, and instructions on running the program on the
TRS-80 (PC-1). Proc. XIII Annu. Mtg. MidAtlantic Veg. Workers Conf., Newark, Del., 21-22 Oct. 1982.

Mills, D.J., C.B. Coffman, J.R. Teasdale, J.D. Anderson, and K.L. Everts. 1999. Progress in the development of a sustainable production system for fresh-market tomatoes. HortScience 34:471 (abstr.).

Neary, P.E. 1992. Commercial staked tomato production in New Jersey. Rutgers Coop. Ext. N.J. Agr. Expt. Sta. Bul. E163.

Pennypacker, S.P., L.V. Madden, and A.A. MacNab. 1983. Validation of an early blight forecasting system of tomatoes. Plant Dis. 67:287-289.

Pitblado, R.E. 1988. Development of a weather-timed fungicide spray program for field tomatoes. Can. J. Plant Pathol. 10:371.

Poysa, V., R.A. Brammall, and R.E. Pitblado. 1993. Effects of foliar fungicide sprays on disease and yield of processing tomatoes in Ontario. Can. J. Plant Dis. 73:1209-1215.

Sandlan, K.P. and T.A. Zitter. 1989, rev. 1992. Scheduling fungicide sprays to control tomato early blight using a modified FAST forecasting program. Plant Pathol. Ext. Rpt. 89-3.

Tietjen, W.H., W.P. Cowgill, Jr., M.H. Maletta, P.J. Nitzsche, and S.A. Johnston. 2001. Stake culture reduces foliar disease and postharvest fruit rot in tomatoes grown under weekly or forecastergenerated fungicide schedules. HortTechnology 11:230-233. 